\title{
Contribution to Social Innovation Theory and Practice: Lessons from a Portuguese Association
}

\author{
Subsídios para a teoria e prática da inovação social: reflexões a partir de uma Associação Portuguesa
}

Subsidios para la teoría y práctica de la innovación social: reflexiones a partir de una Asociación Portuguesa

Naldeir dos Santos Vieira Doutor em Administração / Universidade Federal de Minas Gerais - UFMG Universidade Federal dos Vales do Jequitinhonha e Mucuri - UFVJM / Professor Adjunto II http://lattes.cnpq.br/3123409021367108 http://orcid.org/0000-0001-5624-8345

naldeir.vieira@ufvjm.edu.br

Allan Claudius Queiroz Barbosa Doutor em Administração / Universidade de São Paulo Universidade Federal de Minas Gerais / Professor Titular http://lattes.cnpq.br/2542913266521798 https://orcid.org/0000-0003-1266-5168 allan@ufmg.br

Crsitina Clara Ribeiro Parente Doutorada em Sociologia / Universidade do Porto.
Faculdade de Letras da Universidade do Porto/ Professora Associada com Agregação https://orcid.org/0000-0002-7500-7050

cparente@letras.up.pt

Daniel Paulino Teixeira Lopes Centro Federal de Edor em Administração / Universidade Federal de Minas Gerais http://lattes.cnpq.br/2990415350413529 https://orcid.org/0000-0001-8928-0245 daniel.lopes@globo.com

\begin{abstract}
This study aims to analyze how the actions of a nonprofit association from Portugal impacted on the development and promotion of social innovations. The literature review discusses origins, concepts and processes of this type of innovation, and includes the criteria for evaluation of its results. The analyses were based on the triangulation of semi-structured interviews, direct observation and documentary data research. Results show that, despite not being the focus of the association, actions towards the community quality of life enabled the development of processes and products regarded as social innovations. The main obstacles were financial dependence on the state and local subsidies, ingrained habits and customs of local population, and low levels of active participation of those involved in proposing innovative ideas. However, the association succeeded by relying on the creativity, inspiration, engagement and support from its main leaders, and on the alignment and support of its human resources in the implementation of the strategy.
\end{abstract}

KeyWords: Social innovation, Nonprofit organizations, Associative movement.
Resumo: Este trabalho analisa como as ações de uma associação portuguesa impactaram o desenvolvimento e promoção de inovações sociais. A revisão de literatura discute as origens, conceitos e processos ligados a esse tipo de inovação, incluindo critérios para avaliação do seu resultado. As análises foram subsidiadas pela realização de entrevistas semiestruturadas, observação direta e pesquisa documental. Os resultados mostram que, apesar de não ser o foco da associação, a busca por qualidade de vida dos habitantes do seu entorno fez com que a mesma possibilitasse 0 desenvolvimento de processos e produtos considerados como inovações sociais. Os principais obstáculos identificados foram dependência financeira das subvenções estatais e municipais, hábitos e costumes enraizados da população local e baixa participação ativa dos envolvidos na proposição de ideias inovadoras. Entretanto, a associação obteve sucesso por contar com criatividade, inspiração, engajamento e suporte de suas lideranças principais e com o apoio de seus recursos humanos.

Palavras-Chave: Inovação social, Organizações Sem Fins Lucrativos, Associativismo.
Resumen: Este trabajo analiza cómo las acciones de una asociación portuguesa impactaron el desarrollo y promoción de innovaciones sociales. La revisión de literatura discute los orígenes, conceptos y procesos ligados a ese tipo de innovación, incluyendo criterios para la evaluación de su resultado. E análisis fueron subsidiados por la realización de entrevistas semiestructuradas, observación directa e investigación documental. Se observó que, a pesar de no ser el foco de la asociación, la búsqueda por de la calidad de vida de los habitantes en su contexto local, generó que la misma posibilitase el desarrollo de procesos y productos considerados como innovaciones sociales. Les principales factores restrictivos identificados fueron la dependencia financiera de las financiaciones estatales, los hábitos y costumbres enraizados em la población local y la incipiente participación activa de los involucrados en la propuesta de ideas innovadoras. A pesar de ello, la asociación obtuvo éxito gracias a la creatividad, inspiración, compromiso y soporte de los dirigentes principales y con el apoyo de sus recursos humanos.

Palabras clave: Innovación social, Organizaciones sin animo de lucro, Associacionismo.

\section{INTRODUCTION}

Social innovation has been receiving increasing attention as a topic of interest since the 1990s. Literature in this field emphasizes the contribution of courses and university research programs, such as Stanford, Harvard and Brown, universities in the United States; the Centre de Recherche sur les Innovations Sociales (CRISIS), in Canada; the Business School for the World (INSEAD), in France; and University of Cambridge, Young Foundation, and National 
Endowment for Science Technology and Arts (NESTA), in England (Bignetti, 2011; Ezponda \& Malillos, 2011).

As a result, there has been a considerable growth in the number of studies and publications on social innovation (Pacheco et al., 2015; Montgomery, 2016). Many of these studies, which are mostly case-based, include the definition of concepts and the various meanings of social innovation, alternative approaches, processes or steps for their development and dissemination. In this way, this type of innovation has been promoted to a larger extent, and the experiences of Nonprofit Civil Society Organizations (CSOs) have been highlighted.

These organizations can be considered the most fruitful source to understand the social innovation-related phenomena, as they intervene directly in territorial development, through guided activities for defending collective interests, and have a humanistic sense of common good. Thus, CSOs may be regarded as "laboratories" for the development of innovations that result in new processes, interventions and approaches, or new products and services designed to improve a situation or solve a social problem (CST, 2000). Such innovations, qualified as social, seek the connection among meeting basic needs, improving environmental quality, as well as innovating social relations, governance, empowerment, and social justice (Mehmood \& Parra, 2013). Indeed, it has become common to use the term social innovation interchanged with terms like social economy, social enterprise and third sector (Montgomery, 2016).

However, many aspects remain misunderstood, thus giving reasons that justify the intensification of efforts to understand the environmental conditions that favor sustainability and that spread social innovation in ways that align different interests, agents and resources necessary for their development and dissemination (Oliveira \& Breda-Vázquez, 2012). Moreover, Bouchard (2012), in his studies, presents evidence that not all CSOs are innovative. This situation reinforces the need to intensify researches in this area to better document the potential of the field, as well as its limits to solve large-scale problems.

In this attempt, this study aims to analyze how the actions of a nonprofit association from Portugal have impacted on the development and promotion of social innovations. An in-depth analysis of social innovation is carried out according to criteria of scale, scope, and resonance (Nilsson, 2003), as well as its history, needs to be fulfilled, main requirements, and leading agents related to its development and support. Miro Association (Grupo de Solidariedade Social Desportivo Cultural e Recreativo) was chosen as the unique case, since it acts toward local development, has been a driving force that engages the network of local organizations and people, involves the whole community, and has local and regional impact that is recognized either institutionally or by autochthonous inhabitants and observers. Miro Association is now a reference of giving responses to the different social problems it faces, and of local community empowerment.

The analyses were developed using triangulation of data, carried out through semi-structured interviews with key informants i.e. directors, employees and other stakeholders - direct observation, and documentary research. They allow reflections on the history of the organization and on the activities that affected or restricted actions considered socially innovative.

\section{CONTEXTUALIZING SOCIAL INNOVATION}

Since Schumpeter, in the 1930s, innovation may be seen as a construct that has a strong connotation of obtaining economic value, further resulting in a diversity of meanings, with contributions from different authors. Initially, it was defined as a process that triggers new ideas, practices, and artifacts. It was also defined as new procedures, products, and solutions, as well as a combination of creativity and risk. Then, this idea was applied mainly to technological and industrial areas, by assigning technological innovation. More recently, new concepts have gained notoriety, such as organizational or administrative innovation, market or marketing innovation, and social innovation (Bignetti, 2011).

Social innovation has acquired greater importance since the last half of the twentieth century, despite the fact that studies on the impact of innovations in improving the quality life are not recent. In Klein's view (2013), the emphasis on social innovation has been strengthened by the failures and inconsistencies of the neoliberal growth model that has extended throughout the world since 1980 , and the new approaches to the innovation process, with a view to encourage social development. As a result, the term "social innovation" became part of government and research agendas, thus multiplying contemporary approaches to the theme (Bignetti, 2011).

While the most frequent concept of technological innovation focuses on objects, products, or processes resulting from information and communication technologies, social innovations has focused on contexts that involve people and territories, from a multidimensional perspective (work, health, qualification and others). However, it remains associated with the use of inventions or technological applications that are related to diversified agents involved in achieving systemic social change (Diogo, 2010).

The concept of social innovation emphasizes social transformation, learning processes, and dialogue between different kinds of knowledge and innovation. It largely refers to contributions given to disadvantaged or marginalized segments of society, and for the society as a whole (Phills Jr. et al., 2008).

It is worth noting the two main strands of concept in social innovation. Authors like Mulgan (2007), Pol and Ville (2009) and Ezponda and Malilos (2011) focus on the purpose of innovation. According to them, what qualifies "social" innovation as such is its purpose - solving collective problems -, regardless of its origins or how it is developed. From this perspective, there is a focus on models and programs with social impact and replicability potential in other contexts.

Other authors, such as Klein and Moulaert (2013), McCallum and Hillier (2013), approach that concept by referring mainly to innovation processes: besides their social objectives, social innovations results from activities undertaken by CSOs towards vulnerable people, intervention methodology, and enablement and empowerment of processes. This second approach is characterized by innovations that are developed by associations and cooperatives. 
However, when different approaches are considered, it is believed that regardless of the sector (state, market or CSO) there is a great variety of organizations that can generate social innovation, especially when collaboration exists (Ezponda \& Malillos, 2011). This is also the perception of Mulgan (2010, p. 59), who states: "Innovation that starts in one sector can be taken over by others, and often the most exciting innovations occur at the boundaries between sectors".

Besides, the importance of partnership among the public sector (through policies and service models), the private sector (e.g. ethical finance, corporate social responsibility and new collaborative business), and the third sector, Mulgan (2010) emphasizes the critical role of the family in social innovation. Changes in family behavior have been crucial to increase the effectiveness of social movements, as it can be seen in the cases of slow food and people with special needs.

Indeed, social innovations are rarely just top down or bottom up (Mulgan, 2007; 2010). They reinforce the need for partnership between small organizations, groups and individuals - which are characterized by high creativity, mobility and speed - and large organizations, including governments, companies and large NGOs - which are less creative, but have high capacity for implementation, financial resilience, and scale to make things happen.
These innovations are associated with "solving social problems, usually left aside by public policies and the actions of society in general" (Bignetti, 2011, p. 8). Their objectives range from responding to unsatisfactory social situations to rearranging social roles and structures. So, they are implemented "by social agents who respond to aspirations, meet needs, find solutions as well as have a chance to change social relations, to transform frameworks and propose new cultural orientations" (Levesque, 2006, p. 3).

In lonescu's view (2015), as the existing structures and policies fail to address pressing problems, a lot of hope is placed on social innovation. People have become more aware of the importance of organizing themselves in order to find solutions to the challenges faced by society. Such awareness fostered the development of new organizations or collaborative networks aimed at alleviating poverty and social exclusion.

Those solutions follow different trajectories, which may vary according to the resources available, as well as the interference of propellants and/or restrictive factors. However, when citing Bacon et al. (2008), Oliveira and Breda-Vázquez (2012) state that, regardless of particularities, it is possible to identify patterns that result in similar phases in the social innovation life cycle, as shown in Figure 1.

Figure 1. Phases of social innovation life cycle.

\begin{tabular}{|lc|c|c|}
\hline \multicolumn{2}{|c|}{ Phase } & Description & Obstacles \\
\hline $\mathbf{0}$ & Latent & $\begin{array}{c}\text { Identification of a social need. } \\
\text { Launching of new ideas. }\end{array}$ \\
\hline $\mathbf{1}$ & $\begin{array}{c}\text { Conception and } \\
\text { development }\end{array}$ & Discussion and selection of ideas. & Precipitate abandonment of promising ideas. \\
\hline $\mathbf{2}$ & Mobilization & Adaptation of the institutional context to the innovation & Lack of support, resources or adequate leadership. \\
\hline $\mathbf{3}$ & Generalization & $\begin{array}{c}\text { Incorporation of the social innovation to the practices and routines of its } \\
\text { institutional context. }\end{array}$ & $\begin{array}{c}\text { Opposition moved by established interests. } \\
\text { Embeddedness of previous practices. } \\
\text { Institutional fragmentation. }\end{array}$ \\
\hline
\end{tabular}

Source: Adapted from Bacon et al. (2008 apud Oliveira \& Breda-Vázquez, 2012, p. 525).

The life cycle begins in phase 0 , when a latent social need is identified, thus providing a trigger for the generation of new ideas. The next phase involves the project and the discovery of new processes or products, often with turbulent discussion of new ideas, which can be developed or abandoned. In phase 2 , there is a mobilization that involves the creation of new structures or redirection of existing ones, in order to put the new ideas into practice and pilot them. This process may not continue for several reasons, such as lack of support, resources or proper leadership, or simply because it does not work in practice. But when it works, it reaches a larger scale and becomes part of the main routine in the institutional setting. Phase 3 is the generalization one, which is characterized by strong resistance from the established interests. After generalization, it comes the dissemination stage, in which inter-sectorial and inter-territorial diffusion processes take place through inspiration or replication.

Regarding the criteria to evaluate the results of social innovation dynamics, Parente, Marcos and Diogo (2014) proposed scale, scope and resonance, as used by Nilsson (2003). Scale is related to the number of people and geographical coverage. Scope concerns the multiplicity of social dimensions covered by processes that correlate with and result in inter-related improvements.
Resonance refers to the intensity of integration of the social innovation practices or processes into the mental structures and social practices, thus promoting reinterpretation and appropriation that encourage their reproduction. Many authors define this last indicator as replicability, when there is innovation adaptation from one context to another.

However, Parente, Marcos and Diogo (2014) consider replicability as an indicator of resonance. This idea favors a systemic perspective of the capacity of expansion or replication, discharges prefabricated solutions, and favors flexible and embedded solutions in the communities where they are implemented.

In light of this theoretical foundation, the next section presents the research method used, which includes dimension parameters and indicators that allow a deep analysis of practices developed by Miro Association, a space for interaction and search for collective problem solution.

\section{METHODOLOGICAL PROCEDURES}

In order to implement a qualitative analysis of the practices developed by Miro Associationi, this study uses an interpretative approach to investigate the web of representations and interpretations (both internal and external to the organization) in the 
process that results in innovation, whether in products, services or management models (Lopes \& Barbosa, 2008). Thus, a field research was carried out in a way that considered meanings, motives, aspirations, beliefs, values and attitudes, as well as space of relationships, processes and phenomena that cannot be restrained to simple operationalization of variables.

The case analysis was supported by information obtained from desk research, direct observation, and semi-structured interviews with key informants, particularly required in the context of a study coordinated by Parente (2014). First, we contacted the organization during the Seminar on Solidary Social Economy, held in the city of Rio Maior. In February 2015, during the first meeting with the directors, it was observed how the structure of the Association was held. In this occasion, we had a first joint conversation with several leaders, which included negotiation of data collection terms, document collection and site visit. In July of the same year, there was a second visit, with the main objectives to get more documents and to conduct semi-structured interviews. Systematic observation was carried out during both visits, when data were registered not only through field notes, but also by photographs of the Association's physical spaces and community. On the second visit, there was intensive interaction with the organization staff and beneficiaries during meals and overnight stays. Diversity was the main internal selection criterion, and therefore different members in the organization were chosen to be interviewed: directors, employees, beneficiaries, associates and volunteers. Given this criterion, the choice of interviewees was mediated by the help of Miro Association's president, who informed key contacts and their availability to be interviewed. Finally, 10 respondents with a long history of active participation in activities developed by the Association were selected (selection by convenience, Merriam, 1998). The respondents' profiles are presented in Table 1.

Table 1: Respondents' profile

\begin{tabular}{|c|c|c|c|c|c|}
\hline Interviewees & Function & Age & $\begin{array}{l}\text { Time in post } \\
\text { (years) }\end{array}$ & $\begin{array}{l}\text { Time in the } \\
\text { organization }\end{array}$ & Education \\
\hline Respondent A & President & 56 & 9 & $\begin{array}{c}\text { (Founder) } \\
35\end{array}$ & 12th year \\
\hline Respondent B & $\begin{array}{l}\text { Director of Social Development } \\
\text { Projects }\end{array}$ & 57 & 2 & 3 & $\begin{array}{l}\text { Degree in Primary } \\
\text { Teaching; Graduate Diploma in } \\
\text { Development, Project and Partnership }\end{array}$ \\
\hline Respondent C & $\begin{array}{l}\text { Technical Director of Social } \\
\text { Responses }\end{array}$ & 37 & 6 & 6 & $\begin{array}{l}\text { Degree in Social Work; Master in } \\
\text { Sociopsychology of Health }\end{array}$ \\
\hline Respondent D & $\begin{array}{l}\text { Director of Transportation and of } \\
\text { the Department of Sport and } \\
\text { Youth }\end{array}$ & 33 & 6 & 25 & $\begin{array}{l}\text { Degree in Geography; Master of } \\
\text { Educational Administration and } \\
\text { Management }\end{array}$ \\
\hline Respondent E & Social education promoter & 31 & 5 & 6 & Degree in Youth Work \\
\hline Respondent F & $\begin{array}{l}\text { Responsible for the } \\
\text { administrative and financial } \\
\text { sector }\end{array}$ & 35 & 6 & 6 & 12th year \\
\hline Respondent G & $\begin{array}{l}\text { Manager of Development } \\
\text { Projects }\end{array}$ & 33 & 1.5 & 1.5 & Degree in Sociology \\
\hline Respondent $\mathrm{H}$ & Volunteer & 47 & 1 & 1 & 9th year \\
\hline Respondent I & Associate & 38 & 0.5 & 17 & 9th year \\
\hline Respondent $\mathrm{J}$ & Beneficiary & 67 & 6 & 6 & 6th year \\
\hline
\end{tabular}

Source: Elaborated by the authors based on the data obtained.

A timetable was constructed for semi-structured interviews. The script was improved or modified as needed to obtain other types of data (Godoy, 2006). The main questions, a total of 19, inquired about: a) activities perceived as socially innovative; b) innovationrelated aspects concerning products, processes, services, intervention methods and policies, organization practices and structure; c) how they are developed; d) the reliability and neutralizing factors for their development, as well as questions about the scale, scope, and resonance of identified socially innovative activities. Although the interviews were individual, the research focus at units of analysis referred to the collective and organizational functioning.

In addition to the documentary, analysis of social statutes, 20132014 activity reports, pamphlets, the Miro Con Vida newsletter, the 2015 Strategic Plan and Budget, interviews, and direct observation, the President also filled in an organizational survey.

The analytical model is systematized in Figure 2.

Figure 2. Dimensions of analysis and indicators of study

\begin{tabular}{|c|c|c|}
\hline & Characterization of the Association & Social innovation dimension \\
\hline Indicators & $\begin{array}{l}\text { - Structure } \\
\text { - Number of members } \\
\text { - Target audience } \\
\text { - Main activities } \\
\text { - Products and services } \\
\text { - Field of activity }\end{array}$ & $\begin{array}{l}\text { - Possible social innovations developed and how they were developed } \\
\text { - Perception of range, scope and resonance of socially innovative activities } \\
\text { - Restrictive forces/identification of drivers for social innovation development }\end{array}$ \\
\hline
\end{tabular}

Source: Elaborated by the authors, based on the data obtained

Through content analysis (Bardin, 1977), the recorded conversation transcripts were categorized. Subsequently, these data were entered in a double entry matrix (lines of respondents versus categories of analysis). The matrix was printed and the analysis was carried out directly by the researcher, without using analysis software. Triangulation analysis was performed according to the interviews, field notes, photographs and documentary data 
obtained. Later, the results were analyzed based on the analytical model presented in Figure 2. Section 4 describes the Association and section 5 and subsections discuss the findings for the social innovation dimension presented in Figure 2.

\section{MIRO ASSOCIATION - HISTORY AND ACTIVITIES}

Miro Association was founded in 1978, registered in 1980, and it has dedicated its efforts to sport activities (including athletics and football). The activities that aimed at social action began in 2000 , with the initiative named "Apoio Domiciliário" (Home support), which gained momentum in 2009 with the development of the Complexo Social de Miro (Miro's Social Complex), and started to work with interventions in a nursing home, a day care center and a crèche. Currently, the Association is one of the largest institutions in the Portuguese municipality of Penacova, with a turnover close to a million Euros per year, and around 800 members (Miro Con Vida Newsletter, 2015).

The history of Miro Association is strongly linked to its founder. As there were few leisure options in his community, the founder and his relatives (who lived in Coimbra, but used to spend vacations in Penacova) created the Adventures Group, dedicated to leisure activities, such as building nests for birds. In addition, voluntary groups were active in cleaning water sources and restoring degraded spaces, like walls in public areas. Gradually, the Group started to gain visibility in other locations and to receive invitations for exchange programs and sports events.

Since $\mathbf{2 0 0 0}$ the founder realized that the organization needed to engage other age groups that also had unanswered social demands. Thus, under his leadership the Association has made efforts to be recognized as a Public Utility and Private Institution of Social Solidarity (IPSSii) since 2000 , as a result of its work with elderly and children. Since then, the social aspect has gained prominence, with larger budgets and more employees.

Nowadays, Miro Association has two physical spaces. The first was initially intended for social action, but is now an administrative. It also has a kitchen, a products shop, a museum, a trophy room, a space for socializing and a cash machine for local population use. The second space offers a nursing home, a day care center, home help and a crèche. Both home and day care provide elderly assistance, including: accommodation, food, personal hygiene, clothing, medical and nursing care, entertainment, recreation, and transport. The nursery provides educational intervention, as well as food and transport for young children (Planning and Budget of the Association, 2015).

The Association receives dues paid by its members, fees from its beneficiaries, donations and grants. The two main sources of funding are the state and the municipal grants. It has 50 workers, comprising 45 employees (mostly women, 39), 4 workers providing services independently ( 3 women and 1 man), and one intern. Regarding the workers' functions, 3 are senior technicians in leading roles, 4 are senior technicians without managerial responsibility, and 43 operate as qualified personnel. Last year there were no losses or gains in personnel, which is an indication of low turnover. However, there was a change in the number of members, with an increase of 39 people and one resignation.

In addition to the board chaired by the President and two counselors (managing and fiscal), the Association consists of an executive management team divided into four sections: projects and development (rural development, headquarters and Portugal Tradicional); social (admission process, home help, childhood health and kitchen); youth and sports (indoor football court, training and competition, reception); and operations support (transport, administrative and finance).

Autonomous groups and organizations have also been created. They work in partnership, in close interaction with the parent organization (i.e. the Association), thus optimizing the physical space and human resources, and providing economy of scope and scale in the development of activities. Five organizations with different legal constitutions have been created and become autonomous. Some had a business facet, while others were more collectivists: a cooperative, a transport company, a folklore group, an association for hunting, fishing and another for extreme sports.

The Produtos da Nossa Aldeia (Our Village Products) Cooperative was established in 2012 to meet both the needs of local farmers who have agricultural surpluses, and those of the Association, which has a daily demand for the same products, for domestic consumption. These products are handed to the Cooperative, which sells them to the Association. Part of the production is sold in small shops in the area, and as far as Coimbra.

We often had a surplus of production here. And the group itself, which is an IPSS, wanted these agricultural products. So we tried to see how we could create a document justifying the purchase ... It must be done this way ... And from my conversations with the president and others, we looked at some projects, and then we realized that some institutions in the area were doing this way. (Respondent B)

The second organization, Passengers Transportation, was created in 2012 to provide local transport to meet the demands of local people, and to create a complementary source of revenue for the Association. It was also the cause of a legal problem, because the Association, as an IPSS, could not compete with other companies for the provision of neither public nor school transport, or conduct tours. The solution was to create an independent private company, $99 \%$ owned by Miro Association and the remaining $1 \%$ owned by Rancho, another ring-fenced group:

So, we started the transport company and answered a need, and it also provided an extra income to the Group. After the transport company grew, we had to create a set of skills for tourism, which the company spent two months adapting (...). We now have the shares of the transport company; we have contacts with Spanish companies, and have already provided some services to these agencies. (Respondent B)

In 2003, the Associação para Actividades de Lazer e Desportos Radicais(Leisure Activities and Radical Sports Association) was created. It is an association for leisure activities and radical sports that aims to develop activities for tour groups and participants in extreme sports, such as kayaking in summer. The fourth group is the Rancho Típico de Miro (Miro's Typical Ranch), created in 1986 , which became autonomous in 2003 , in the form of association. This autonomous group seeks to preserve local traditions and customs, and make them available tothe public through 
presentations in festivities. Finally, the fifth group is the Associação dos Amigos da Caça e Pesca (Hunting and Fishing Friends Association), an association for hunting and fishing also created in 2003, which provides recreation for practitioners of these activities.

Miro Association and its autonomous organizations have the same physical structure, as well as the same diverse human resources engaged in providing as maximum social response as possible for local people (lonescu, 2015). The view of Respondent A was that the empowering smaller groups became necessary in order to create a tighter control over the budget and to expand the political power of the group, since it previously was just an association that sought access to public resources.

When participation is the issue under analysis, statements alternate between positive and negative. On one hand, they often highlighted positive aspects related to the high involvement of the directors; on the other, Respondents B, C, D and G reported weaknesses in obtaining effective participation of a larger number of people.

Of course these activities that involve working differently from our normal day to day, in our time off, end up always being the same. Really. It is a shame there's not more involvement from those workers who are more at the front line, and generally work more with the elderly. They don't get much involved. They get on with their normal work, do it very well and leave. They aren't up to stay and help. (...) Just a few of them are. (Respondent C)

The passivity of a portion of the members leads to a concentration of the protagonist role on the board, which always pushes for implementation. This is why participation is the main concern of Respondent $B$, as it is necessary to think about how the Association can move from a leadership role that almost forces the other members to participate to a greater collective involvement. There is a lack of people who can promote a link between the various projects of the organization, and that do beyond their basic tasks.

\section{THE DEVELOPMENT OF SOCIAL INNOVATION AT MIRO ASSOCIATION}

When informed that this study considers social innovation as new products, services, processes, approaches or interventions to develop and improve a situation, or solve a social problem, strengthening assumptions of action capacity, and transforming behaviors of people in order to improve the social welfare (Phills Jr. et al., 2008; Diogo, 2010; Moulaert, Maccallun, \& Hillier, 2012), all respondents considered the above practices to be usual at Miro Association.

Despite Respondent B stating that the Association does not deliberately pursue the development of social innovations, it was almost unanimous that the Association was a space for developing this type of activities, since it aims at improving the quality of life for the local population. The following points were highlighted as socially innovative actions: setting up a space for occupation and expansion of local population's income; creating new business opportunities associated with the local potential; the Projeto Portugal Tradicional (Traditional Portugal Project); the way the Association structures itself in a collaborative network; how it intervenes to guarantee the target audience's quality of life; and differentiated practices that the main goal is to rescue and appreciate the local culture. In spite of the questionable originality of the above practices, they are aligned with the concept proposed by Phills Jr. et al. (2008), because they are new to the territory.

It is observed that most of these innovations resulted from actions aimed at overcoming the local shortage of jobs, especially for young people. Penacova has no manufacturing industries and this reduces job opportunities. The cooperative was created to alleviate this problem as well as to develop and market different food products, such as olive oil with herbs and flower of salt, or even to encourage product manufacture, such as ceramics and crafts. Moreover, in an attempt to take advantage of the local potential, new business initiatives were developed as in the case of extreme sports:

Maybe the factories are going to close. People are unable to create their own jobs. I'm now trying to create these conditions for some people, and I'll give you an example: here, behind me [shows ceramic products], these girls made them... These are ceramics. So ... the school has created a course in pottery... And then I was a judge in their school, to rate them. After seeing the work that some of them did, I asked what their expectations for the future were. And they couldn't point out any. And they have skills. And I issued a challenge: there is no way, no way you could launch your own job. You have no money. There are no ceramic plants here, then go to agriculture and work in the fields. But I said: I will create conditions, I will buy an oven, I will buy equipment and will buy glaze. I will not give you a job. I'm not able to give you jobs. But I will create the conditions for this. Now I need to know who here will join our cooperative and so on. Like our colleagues who provide potatoes and onions. Our cooperative is a cooperative of agriculture, services and arts... Do you want to be member? We will start to paint a few things ... [pauses to display some products]. Whoever comes to Miro can take our spirit home; we have a mill, one boat (miniature ceramic). Let's start doing these little things, so those who come to Miro, to Penacova, can take a simple souvenir with them. (Respondent A)

The Project and Development Section was created to analyze and implement new possibilities, which resulted in the expansion of the Association's scope. The creation of autonomous structures articulated in a network, for its innovative character, was responsible for the Association's renown in Portugal.

Another innovation is the project named Portugal Tradicional, which seeks to attract tourists to the region through a mobile phone application that can be downloaded for free from the Association's website. The application shows maps and tells where one can find typical products of Portugal, detailing their location, opening hours and other options of business in the region. A list of farms, vineyards, sightseeing sites, and cultural groups and their respective locations are also available, which brings Portuguese producers and tourists from different countries together.

Another important aspect of social innovation is the Association's way of intervention. In the view of the Respondents $C$ and $E$, the treatment that seniors receive at the nursing home is different from the other homes in the area, which mostly encourage them to stay seated and watching TV. In the Association's home, physical and cognitive activities (exercise classes, medical therapy and nursing) are performed, and the elderly engage in manual activities (production of scones and jams, meat preparation, and peeling potatoes and fruit), which make them feel included in the institution. They also have trips to rivers, beaches, malls and libraries and participate in events that involve the whole family. 
As part of the festivities, the Festa do Barqueiro (Boatman's Party) was also mentioned by the respondents $A, B, C, D, E$ and $G$ as a social innovation. This is due to the way people were involved in its production, not only as target audience, but also as actors, to rescue scenarios and typical practices from the last century.

With this theater, so to speak, we create our traditions, and for me this is already an innovation. And to see seniors saying: "Oh, I remember my childhood days!". When they tell me this, I find it fantastic to have this appreciation. (Respondent D)

When asked about the way that these ideas or innovative proposals have been developed, Respondents A, B, C, D, E, G, H and $I$ were unanimous in considering that the protagonism is concentrated on the founder and current president, with some newer initiatives elaborated jointly with the Director of Projects and Development. This situation was highlighted as both a strength and a weakness of the Association, because such people are promoting activities, but at the same time, many proposals are in fact conditioned to them.

I have known the President from a long time. (...) But he has this ambition to never stop and always go further and do different things. And I think many have gained from this, for example this area of Friúmes Parish has developed a lot. Especially Miro. (Respondent E)

Many [ideas] of [the President], of the President, yes. Because he always has an innovative idea and so does [the Director of Projects and Development]. So, when the two began working more in a partnership, we noted that they started to have a lot more ideas. Also, we have a lot of technical team meetings with the [President] and these things, these ideas come, and let's take a risk. (Respondent C)

However, the implementation of ideas was only possible with the cooperation of a larger number of stakeholders. Despite the centrality of the President, participation is sought through meetings in which there are ideas, and proposals are debated, analyzed and considered in terms of feasibility of implementation (Respondent $G$ ). According to Respondent $G$, the Association also sets three-year action plans, involving statutory managers, senior technicians (supervisors and others) and operating qualified staff in its preparation.

Concerning the appropriation of experiences from other contexts, these results corroborate the prospects by Parente, Marcos and Diogo (2014): a mere replication was unfeasible, that is, the Association had to adjust these experiences to its local reality. Respondent G illustrates this point with the Portugal Tradicional project: its implementation required the creation of a smartphone application, as the Association did not have financial resources to print pamphlets. Another fact that hindered replication was the typical behavior of local people. The Portugal Tradicional model faced barriers because owners were not accustomed to open their properties to tourists.

\section{Perceiving scale, scope, and resonance of the social innovations}

The analysis of social innovations indicators, which derived from the interviewees' perception, point out a positive convergence regarding scale and scope indicators, and some uncertainty regarding replicability, due to their intangible nature and measurability.

As for the scale (Nilsson, 2003; Diogo, 2010), taking the community population of Miro as reference (250 voters), it is observed that the association involves a significant percentage of locals. In terms of direct beneficiaries, various were mentioned: employment of 50 workers (most of them in their own location), 40 helpers in home care (from all over the district of Coimbra), 30 people benefited from the Home Support Service, 15 from the day center and 5 from the crèche. Add to this the more than 120 athletes and 31 members of a scouts group. Respondent D said that the Group works directly in their routine activities with approximately 300 people, including workers, seniors, children, indoor soccer players and others. When sporadic activities are done, such as the Festa do Barqueiro, this number rises significantly, since it involves the whole village community and attracts people from the all over the region. In this party, about 2000 people were present. The project Portugal Tradicional was cited as the biggest, because it was developed for the entire country.

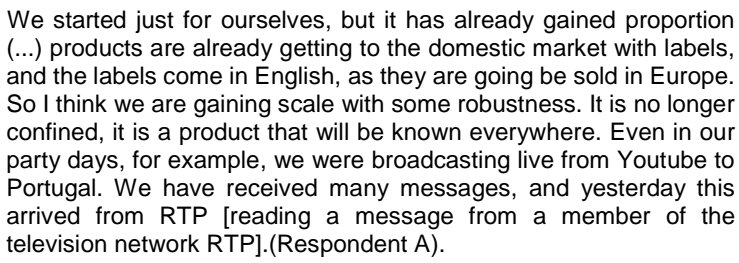

Concerning its scope (Nilsson, 2003; Diogo, 2010), the pursuit of an extensive sustainable development included different social, cultural, economic and environmental dimensions. The Association deals with issues like generating income, rescuing cultural practices and skills, overcoming basic social problems, such as care for the elderly and children, and others related to leisure and education. These issues were addressed in an integrated way, given the diversity of projects and actions developed by the Association, as shown in Figure 3.

Figure 3. Association projects versus impacted dimensions

\begin{tabular}{|c|c|c|c|c|c|c|c|}
\hline \multirow{2}{*}{$\begin{array}{c}\text { Projects and } \\
\text { activities }\end{array}$} & $\begin{array}{c}\text { Generation of } \\
\text { jobs and income }\end{array}$ & $\begin{array}{c}\text { Qualifications/Educati } \\
\text { on }\end{array}$ & Leisure & Culture & $\begin{array}{c}\text { Political } \\
\text { engagement }\end{array}$ & Social Safety & Environment \\
\hline $\begin{array}{c}\text { Home, day care, } \\
\text { home care }\end{array}$ & $\mathbf{X}$ & $\mathbf{X}$ & $\mathbf{X}$ & $\mathbf{X}$ & & $\mathbf{X}$ \\
\hline Co-op & $\mathbf{X}$ & $\mathbf{X}$ & $\mathbf{X}$ & $\mathbf{X}$ & $\mathbf{X}$ & $\mathbf{X}$ & \\
\hline Portugal Tradicional & $\mathbf{X}$ & $\mathbf{X}$ & $\mathbf{X}$ & $\mathbf{X}$ & \\
\hline $\begin{array}{c}\text { Hunting, extreme } \\
\text { sports and folklore } \\
\text { association }\end{array}$ & $\mathbf{X}$ & $\mathbf{X}$ & $\mathbf{X}$ & $\mathbf{X}$ & $\mathbf{X}$ & $\mathbf{X}$ \\
\hline Transport company & $\mathbf{X}$ & $\mathbf{X}$ & $\mathbf{X}$ & $\mathbf{X}$ & $\mathbf{X}$ & $\mathbf{X}$ \\
\hline $\begin{array}{c}\text { Exchanges and joint } \\
\text { networks }\end{array}$ & & $\mathbf{X}$ & & & & $\mathbf{X}$ & $\mathbf{X}$ \\
\hline
\end{tabular}

Source: Elaborated by the authors, based on the data obtained. 
(a resonance indicator, according to Diogo, 2010), respondents $A$, $B, C, D, E, G, H$ and I pointed out that their representatives have constantly been invited to participate in forums and events to give presentations on the experiences of each group.

Today we were invited by Algarve. Three weeks ago we were in Bragança. In Bragança, Rio Maior, Lisbon, Porto, Leça, São Pedro do Sul. We have been invited a lot to go and pass our message about what we do, because in order to help other places, other villages, they need to know how these things work. (Respondent A)

However, respondents do not know whether the Association's ideas that were developed and shared were indeed implemented. According to Respondent $\mathrm{G}$, in the city, some institutions follow the same path, but yet few perform activities that go beyond their scope, thus restricting them to meeting their members' social demands. Many are inward-looking, but no interviewee seems to be unaware of the feasibility in replicating the Miro model.

\section{Perceiving restrictive and leading forces to social innovations}

The hindering factors to develop social innovations at Miro Association were both internal and external. The difficulty to align diverse interests and agents is prominent, and it is also a concern of Oliveira and Breda-Vázquez (2012). Internally, diversity of people and interests had a direct impact on their participation and engagement. Externally, this diversity affected political articulations, the access to resources, and the definition of policies to support actions that were implemented. The overcoming of this barrier can be credited to the main leaders' persistence, whose efforts had resulted in the formation of collaboration networks, to the inspiration of individuals engaged, and to the facilitation of formal and informal training processes to develop their competencies. The restrictive forces highlighted by the interviewees focused on the need of expanding funding sources for socially innovative practices. Meneses (2010), Bouchard (2012) and Chalmers (2012) also emphasized this need. In the case of Miro Association, there is a need to diversify its funding sources through the generation of internal streams of revenue.

According to interviewees, financial dependence, especially from the state and local government, serves as the main social innovation development barrier to be overcome by the Group. Many grants aimed at Social Safety have specific destination, which makes problematic to carry out practices that are beyond the scope common to social action. Such barriers require constant political articulation with local public managers. Mulgan $(2007 ; 2010)$ and Ezponda and Malillos (2011) argue that when there is an alignment, proposals advance, but when there is not, it is difficult to find support for the implementation of innovative actions. The high turnover of political representatives makes it much more unstable for long-term support to develop activities.

As social innovation requires profound changes in behavior (Levesque, 2006; Mulgan, 2010; Bouchard, 2012; Klein et al., 2012; European Commission, 2013; Pue et al., 2016), rooted habits and customs that characterize local culture were also considered major restrictions to the implementation and sustainability of new ideas, thus requiring more attention to prioritize actions and forms of intervention that could overcome cultural resistance. The concept of culture as a hallmark and distinctive trait, a powerful and permanent feature of the social structure, explains the behavior in sociological literature, and it has an anthropological origin, especially in the work of the classical structuralisms. Later, in Bourdieu's (2007) work on mechanisms of reproduction, he developed the concept of habitus, in which cultural capital is understood as a set of values, beliefs, myths and symbols associated with a social class. Habitus appears as a more promoting dimension of the maintenance of structures, of mobilization of new behaviors and attitudes.

If we apply these concerns into Miro's context, it is possible to infer the Portugal Tradicional project did not achieve as much success in Portugal as in France, because Portuguese owners were not accustomed to foreigners staying in their region. As there were no well-defined obligations between the parties, owners did not see this as an opportunity to obtain income from tourism (Respondent G).

Portugal Tradicional is an opportunity for a motor home traveler to visit a small farm or vineyard, and stay overnight. The idea of letting a stranger sleep in your property doesn't appeal to everybody. Because having a tourist a whole day, a whole night and the day next ... there is no obligation between the parties. But they explore, try our products and then they still can stay until the next day and experience more things. What does the owner gain? Visibility. Those who visit will then talk to others. It doesn't cost anything. The tourist, alone, is autonomous. (....) We are much smaller, and acceptance is more difficult. Initially, for people who have never opened their doors to strangers, it's difficult. They don't see what they can gain from it. They can't realize the purpose. But, gradually, people will go on talking and stimulating. (Respondent $G$ )

In the view of respondent $\mathrm{E}$, cultural resistance drove the need for preparing the ground, which makes idea implementation a time consuming task. In order to ease the acceptance of innovation, and increase the participation and the involvement, it was necessary to change the mindset - a condition for generalization (Oliveira \&Breda-Vázquez, 2012), the third phase of the social innovation development process. The cultural issues were also associated with disbelief and conformism of those involved. Many ideas implemented by the group were discredited, especially by the representatives of local public institutions, one of the main financiers of the institution.

Miro's community isolation was also cited by respondents $D$ and $G$ as a constraint that leads to poor visibility of its products in Portugal. In addition, Respondent $E$ highlighted the fact that people are not always available to serve in the group due to difficulties in conciliate personal and professional life. However, all respondents said that the Association has been able to overcome these difficulties and attributed the credit to the principal leaders who were considered strong and encouraging.

[They] go against the tide and everything, otherwise every time there was an obstacle they would have stopped, and would never have gone anywhere. (Respondent G)

Respondent $\mathrm{C}$ considered the restlessness of the leaders and their commitment to actions directed to social change as factors that favor social innovation. Respondents $E$ and $G$ also emphasized that the knowledge possessed by the board about culture, traditions, and community's problems and potential have facilitated the perception of what may or may not have an effect on the population.

Despite the low participation of workers and associates was a problem, the agreement between the executive board and the chair 
was also considered by the Respondents $C$ and $G$ a facilitator of the group's commitment to the implementation of activities. Although part of the board was considered passive in making proposals, there is a lot of goodwill and collaboration aiming the success of the activities.

Other facilitators for the emergence of new ideas and the implementation of social innovations are networking (The Australian Public Service, 2007; Mulgan, 2007; 2010; Pol \& Ville, 2009; Ezponda \& Malillos, 2011; Moulaert, MacCalum, \& Hiller, 2013), the group's openness to new people, such as visitors, and the exchange and cooperation in the initiatives, as said by respondents $A, B, C, D$, $\mathrm{E}, \mathrm{G}$ and $\mathrm{H}$.

Respondents A, B, C, D, G, H and I highlighted the membership to Rede das Aldeias Inovadoras e Ativas, or Network of Innovative and Active Villages (AIA Network), and to Rede Colaborativa do Mondego, or Collaborative Network of Mondego. The first articulates organizations throughout Portugal from Rio Maior to Caldas da Rainha, and enables discussions and the exchange of ideas and experiences through meetings and presentations about what is being done in the communities. The second operates at local level, and articulates small producers in order to exchange experience and make business together. In face of the complexity brought by everyday problems, networks were considered crucial in defining and implementing strategies - of which results became sustainable in the long term - and in extending the reach and variety of impacted dimensions. It was also highlighted the importance of establishing partnerships, as they enhance common problems resolution and the access to scarce resources.

In fact, this situation relates to Bouchard's (2012) question on whether CSOs alone can solve problems on a large scale. As for Miro Association, the answer to this question is negative, since there were difficulties for acting, mainly because of the lack of support from public institutions. This situation also reinforces Mulgan's (2010) model, which highlights the need for engagement among different agents, so that there is real social innovation. It is noteworthy that Miro Association deeply altered the social relations in the community through partnerships, especially within the scope of the services provided. The organization has pointed out emerging social needs, thus enabling engagement between local councils and public institutions. Therefore, Miro Association has acted as a trigger for creating new practices, which resemble those that led Levesque (2006) to emphasize the importance of the proximity between this type of association and local populations, facilitating engagement and citizen participation.

Figure 4 synthesize the development of social innovations in Miro Association according to the framework presented by Oliveira and Breda-Vázquez (2012).

Figure 4. Reflections on the social innovation process of Miro Association

\begin{tabular}{|c|l|l|l|}
\hline & \multicolumn{1}{|c|}{ Phase } & \multicolumn{1}{|c|}{ Description } & \multicolumn{1}{c|}{ Operation of Miro Association } \\
\hline $\mathbf{0}$ & Latent & $\begin{array}{l}\text { Identification of a social need. } \\
\text { Launching of new ideas. }\end{array}$ & $\begin{array}{l}\text { Social needs arising from various demands of the local population were discussed in regular meetings and } \\
\text { planned with the involvement of the entire group. However, respondents signaled that most of the } \\
\text { implemented ideas were originated from board members, emphasizing the role of the founder and current } \\
\text { president. }\end{array}$ \\
\hline $\mathbf{1}$ & $\begin{array}{l}\text { Conception and } \\
\text { development }\end{array}$ & Discussion and selection of ideas. & $\begin{array}{l}\text { To exercise strong leadership, the Association's founder and current president had to approve the ideas, } \\
\text { thus obtaining legitimacy and cooperation of other officers, employees and associates. However, the } \\
\text { involvement of people could be seen as less substantive, since few were predisposed to make proposals, } \\
\text { hoping instead that the board members would make them. }\end{array}$ \\
\hline $\mathbf{2}$ & Mobilization & $\begin{array}{l}\text { Adaptation of the institutional context to } \\
\text { innovation }\end{array}$ & $\begin{array}{l}\text { There was a wide acceptance and engagement of the majority of those involved in the success of proposals } \\
\text { to be implemented. It was highlighted both good management performance of the Association's leadership } \\
\text { and political articulation for accessing necessary resources. }\end{array}$ \\
\hline $\mathbf{3}$ & Generalization & $\begin{array}{l}\text { Incorporation of the social innovation to the } \\
\text { practices and routines of its institutional } \\
\text { context. }\end{array}$ & $\begin{array}{l}\text { As much as respondents emphasized the openness of employees and associates to put the proposals into } \\
\text { practice, the institutionalization of these ideas faced resistance, and required changes in their behavior. } \\
\text { Habits, fear of novelties, disbelief and divergence of interests were the main bottlenecks. Respondents } \\
\text { were unanimous in stating that these issues could be overcome through persistence from the leaders. }\end{array}$ \\
\hline $\mathbf{4}$ & Dissemination & $\begin{array}{l}\text { Transfer of innovation to other institutional } \\
\text { contexts. }\end{array}$ & $\begin{array}{l}\text { There was dissemination of the Association's practices through the establishment of networks, participation } \\
\text { in forums, and conferences, and exchange of information. However, evidences of implementation of these } \\
\text { practices in other contexts were not presented. }\end{array}$ \\
\hline
\end{tabular}

Source: Elaborated by the authors, based on the data obtained.

\section{CONCLUSIONS}

By thoroughly identifying the socially innovative actions described in the previous sections, interviewees from Miro Association reinforce the observations of Levesque (2006) and Moulaert, Maccallum and Hillier (2013), who consider the field of CSOs fruitful to social innovation development.

Back to this study objective -to analyze how the actions of a nonprofit association from Portugal have impacted on development and promotion of social innovations-it should be noted that, as much as Miro Association does not act deliberately towards "innovation", its aim to articulate actions that seek to overcome local social problems - and to improve quality of life in the community-allowed the implementation of several innovative proposals. It helped to start off new structures and interventions, as well as it changed the local models of production, marketing, and organization. The Association's actions have strengthened the community identity, thus inspiring reflection, and suggesting alternatives and effective actions to address existing problems.

When analyzed under the criteria of scale, scope and resonance, it was observed that the socially innovative actions previously discussed have a direct impact on the lives of the inhabitants in the area. It is noteworthy that the Association is a private institution that generates a lot of jobs in the county. The various projects and activities developed have contributed to a more sustainable development by targeting social, economic, political, cultural and environmental dimensions. However, despite the Association renown throughout Portugal, thus becoming a reference and being invited to seminars, forums and collaborative networks meetings, respondents do not know whether their actions have been implemented in other contexts.

The main barriers to social innovation development were the reliance on state and local subsidies, the ingrained habits and customs of the local population, and the low levels of active 
participation from those involved in proposing innovative ideas. However, the association succeeded by relying on creativity, inspiration, engagement and support from its main leaders. The alignment and engagement of other employees and associates were also crucial for the effectiveness of the proposals.

The case of Miro Association conclusively shows that, despite being a collective workspace, the success depends on isolated individuals that can exert a strong influence on organizational dynamics, especially when they occupy leadership positions. The social innovations identified in this study did not originate from collective creation, but from actions of a few individuals who had different answers to the same stimuli and situations experienced. However, the development of these innovations was strongly influenced by these individuals' experience and direct contact with demands and potentials of the region.

The main limitation of this work is related to the nature of the case study method itself, which makes it impossible to extend the analyses presented here to other contexts than the scope of the respondents shortlisted by the president. Consequently, as a suggestion for future studies, in addition to conducting a survey with a representative sample of $\mathrm{CSO}$, it is our proposal to increase the number of cases. This proposal has already being carried out by the first author, as an attempt to compare Brazilian and Portuguese CSOs experiences in the field of social innovation.

\section{REFERENCES}

Bardin, L. (1977). Análise de conteúdo. Lisboa: Edições 70 Ltda.

Bignetti, L. P. (2011). As inovações Sociais: uma incursão por ideias, tendências e focos de pesquisa. Ciências Sociais Unisinos, 47(1), 3-14.

Bouchard, M. J. (2012). Social innovation, an analytical grid for understanding the social economy: the example of the Québec housing sector. Serv Bus, 6, 47-59.

Chalmers, D. (2012). Social innovation: an exploration of the barriers faced by innovating organizations in the social economy. Local Economy, 28 (1), 1734.

Bourdieu, P. (2007). A economia das trocas simbólicas. 6. ed. São Paulo: Perspectiva.

CST - Conseil de la Science et de la Technologie. (2000). Innovation Sociale et Innovation Technologique: l'apport de la recherche em sciences sociales et humaines. Sainte-Foy Québec: CST. Retrieved on August 20, 2012, from http://www.cst.gouv.qc.ca.

Diogo, V. (2010). Dinâmicas de Inovação Social e suas Implicações no Desenvolvimento Espacial: Três Iniciativas do Terceiro Sector no Norte de Portugal. Dissertation in Hazards, Cities and Spatial Planning, Portugal.

European Commission. (2013). Guide to Social Innovation. DG Regional and Urban Policy and DG Employment, Social affairs and Inclusion/EC. Luxembourg.

Ezponda, J. E., \& Malillos, L. M. (2011). Cambio de Paradigma en los Estudios de Innovación: El giro social de lãs políticas europeas de innovacion. ARBORCiencia, Pensamiento y Cultura, 187(752), 1031-1043.

Godoy, A. S. (2006). Estudo de caso qualitativo. In C. K. Godoi, C. K., R. Bandeira-de-Melo, R., \& Silva, A. B. Pesquisa Qualitativa em Estudos Organizacionais: paradigmas, estratégias e métodos. São Paulo: Saraiva.

Ionescu, C. (2015). About the conceptualization of social innovation. Theoretical and Applied Economics, 22(3), 53-62.

Klein, J. L. (2013). Introduction: social innovation at the crossroads between science, economy and society. In F. Moulaert, D. Maccallum, A. Mehmood \&

'The association has authorized its identification for the purpose of this publication.
A. Hamdouch (Org.). The International Handbook on Social Innovation. Cheltenham - UK: Edward Elgar.

Klein J. L., Fontan, J. M., Harrisson, D., \& Levesque; B. (2012). The Quebec System of Social Innovation: a focused analysis on the local develop ment field. Finisterra, 47 (94), 9-28.

Levesque, B. (2006). Le potentiel d'innovation et de transformation de l'économie sociale : quelques éléments de problématique. Quebec: Bibliothèque et Archives nationales du Québec.

Lopes, D. P. T., \& Barbosa, A. C. Q. (2008). Percursos TeóricosMetodológicos nos Estudos sobre Inovação: como as pesquisas tratam o fenômeno? Anais do Encontro de Estudos Organizacionais - EnEO, Belo Horizonte, MG, Brasil, 1.

Mehmood, A., \& Parra, C. (2013). Social innovation in an unsustainable world. In F. Moulaert, D. Maccallum, A. Mehmood \& A. Hamdouch (Org.). The International Handbook on Social Innovation. Cheltenham - UK: Edward Elgar.

Meneses, J. W. (2010). Liderança e Gestão de OSFL. In. Azevedo, C., Franco, R. C., \& Meneses, J. W. Gestão de Organizações Sem Fins Lucrativos: o desafio da inovação social. Porto: Uniarte Gráfica S. A. $135-$ 162.

Merriam, S. (1998). Designing the study and selecting a sample. In S. Merriam (Org.). Qualitative research and case study applications in education. San Francisco: Jossey-Bass.

Miro Con Vida newsletter. (2015). Special issue, jan. 2015.

Montgomery, T. (2016). Are Social Innovation Paradigms Incommensurable? Voluntas, 27, 1979-2000.

Moulaert, F., Maccallum, D., \& Hillier, J. (2013). Social Innovation: intuition, precept, concept, theory and practice. In F. Moulaert, D. Maccallum, A. Mehmood \& A. Hamdouch (Org.). The International Handbook on Social Innovation. Cheltenham - UK: Edward Elgar.

Mulgan, G. (2007). Social Innovation: what it is, why it matters and how it can be accelerated. London: The Basingstoke Press.

Mulgan, G. (2010). Inovação social. In C. Azevedo, R. Franco \& J. W Menezeso (Org.) Gestão de Organizações Sem Fins Lucrativos: o desafio da inovação social (pp. 51-74). Porto: Uniarte Gráfica S.A.

Nilsson, W. O. (2003). Social Innovation: an exploration of the literature. McGill University.

Oliveira, C., \& Breda-Vázquez, I. (2012). Creativity and Social Innovation: What Can Urban Policies Learn from Sectoral Experiences? International Journal of Urban and Regional Research, 36(3), 522-538.

Pacheco, A. S. V., Santos, M. J., \& Silva., K. V. (2015). Social Innovation: a bibliometlic research. Anais do 5o CIRIEC International Research Conference on Social Economy, Lisbon, Portugal, 5.

Planning and Budget of the Association (2015). Miro Association.

Parente, C. (2014). Empreendedorismo Social em Portugal. Porto: Universidade do Porto.

Parente, C., Marcos, V., \& Diogo, V. (2014). Sobre inovação e empreendedorismo social. In C. Parente (Org.). Empreendedorismo Social em Portugal. Porto: Universidade do Porto.

Phills Jr., J. A., Deiglmeier, K., \& Miller, D. T. (2008). Rediscovering Social Innovation. Stanford Social Innovation Review.

Pol, E., \& Ville, S. (2009). Social innovation: Buzz word or enduring term? The Journal of Socio-Economics, 38, 2009, 878-885.

Pue, K., Vandergeest, C., \& Breznitz, D. (2016). Toward a Theory of Socia Innovation. Innovation Policy Lab White Paper.

The Australian Public Service. (2007). Tackling Wicked Problems: A Public Policy Perspective. Australian Government. Australia.

\section{ACKNOWLEDGEMENTS}

The authors thank the Coordenação de Aperfeiçoamento de Pessoal de Nível Superior (CAPES) for granting scholarship to the first author during his exchange program in Portugal. The funders had no influence on the study design, data collection and analysis, decision to publish, and preparation of the article.

ii In Portugal, the title of IPSS is assigned to organizations that carry out activities of public interest. In practice, it is similar to the Organizations of Civi Society of Public Interest (OSCIP), in Brazil. 